Human Ethology Bulletin 33(3) - Special Issue to commemorate the life of Irenäus Eibl-Eibesfeldt (2018): 27-33

\title{
EIBL:
}

\section{Loving The ENDURing Presence of LitTle LIFE}

\section{Bill Charlesworth}

Red Wing, MN, USA

At a dinner during a conference in Minnesota in 1965, a sun-tanned visiting speaker appeared very drowsy. It was jet lag, so we excused him and waited for his head to soon nod into his soup. It did not, despite my strong wish for an interesting spectacle. After dinner, the visitor recovered and gave an energetic and very novel talk, especially for the psychologists present. For a biologist, he knew a lot about behaviour and for a speaker whose first language was not English, he was very convincing. Eibl was so convincing, our department chair insisted we invite him for a semester. We did. He came and, wanting to practice my German and learn more about ethology, I volunteered to attend his seminar and run the film projector he needed for class. As it turned out, 
he had enough film footage for three semesters. He also had so many exciting things to say, the number of students who came to his second lecture doubled. And each subsequent class grew a bit larger. This meant moving to a larger classroom. By the time the class was completed, we had moved three times. In my experience, such a phenomenon is unusual; most visiting speakers run out of gas early in the semester. However, Eibl was different. Word got around and by the time he gave a university-wide lecture, he needed the largest auditorium on campus. Eibl's visit was my introduction to ethology. But it was all words. I wanted to see it in action. I soon got it. Eibl asked me if I wanted to accompany him to Curacao to study various forms of marine life. Just as I was going to say yes, I remembered the film he showed in class depicting him and Hans Hass surrounded in a coral reef by sharks. My reaction to his request slowed down considerably. But then why not? I blurted out yes, went home, started doing pushups and reading everything I could about reefs and fish.

On the plane trip, Eibl told me everything one needed to know about coral polyps as well as more. It became clear I was in for an education, but I would have to work for it. My main job was to follow Eibl into the water with the equipment he would need to photograph fish. This meant first flopping like a drunken seal across coral reefs wearing very large flippers which I never wore in my life. It also meant dodging sea urchins. They rested on the sides of the reef waiting calmly for me to have a body part impaled on them as soon as the surf slammed me into their territory. But a Mutsprobe is a Mutsprobe. To refuse one would have depressed me for decades.

The first real Mutsprobe came on the second day in a heavy sea when I was sure I would drown ... until Eibl calmly glided over to me and told me to relax and think of water as a "friendly element." I did and here I am today, living proof he was right. At word from some locals that sharks were seen in the area, Eibl decided we should be prepared for the following day when we were to explore beyond the coral reef in much 
deeper waters. Being tool making primates with numerous angeborene skills, we took two old brooms, cut the brushes off them, drilled a hole in one end of the handle and stuck a leather thong through the hole. We then tied the thong into a loop big enough to slip over our shoulder. In the other end of the pole, we pounded in a long nail, then cut off its head with a hacksaw and filed it down into a point. Now what? Eibl's answer: Use it to punch the nose of a curious shark if it gets too close. Great! I felt safe and powerful. Hand weapons do it every time... also angeboren.. After we were out beyond the reef, Eibl, equipped with his scuba, began peacefully checking out eels on the sandy sea bottom. Suddenly, the creature appeared swimming toward us. To this day I swear he was at least four meters long and had a crescent mouth that really scared me. Remembering another two of Eibl's pithy instructions, don't panic and swim with regular movements, I gently left my post and paddled backwards towards the reef. Spotting Eibl's bubbles, the sea monster turned to inspect them. At this moment, I thought it could be construed by future historians that it was cowardly of me to leave my post. But then I thought: Why two sets of fatherless children? Why not just one? Years later, I learned that my reaction was biologically adaptive. So was Eibl's reaction to the shark. He saw the shark's shadow and immediately became as quiet as an Austrian at a Mozart concert (also angeboren). The shark left and human ethology happily benefited thereafter. On Bonaire, an island near Curacao, we drove out to a desert to look at lizards. My job was to lift a boulder while Eibl stood poised to catch the lizard that was resting peacefully under it. Lorle Eibl, our head organiser who kept us civilised on the expedition, stood nearby with a sock. The lizard would be put into the sock for visual inspection and then released. It was hot work. Strangely, I don't recall if we caught any lizards, but I do recall a local inhabitant telling us he remembered Eibl looking for lizards years earlier (on his Xarifa voyage, I believe). The children in the neighbourhood who watched Eibl doing it, continued to imitate his behaviour years later - one lifting rocks, another with a sock in hand. I 
told Eibl that's how fixed action patterns get started. He was not amused but smiled and kept trudging after lizards. While lizard hunting, I learned a new biology lesson. It happened when a cactus lobe attached itself to my pants leg and stayed there. A second lobe did the same. Why? I asked Eibl. What is the adaptive value of such "stupid behaviour"? Without a pause, Eibl's answer was "transport" and kept going. DNA dispersion of course. The Curacao expedition did it. I had to learn more ethology, so I made every attempt over the years to join Eibl and his growing group of human ethologists. This also meant going to Andechs, the Benedictine Abbey near Eibl's research station. The ritual was always the same - first check out the beautiful Baroque Church, then the interesting souvenir shop to remind friends I was in good company, then head to the Biergarten.

Afterward, we'd wade into a pond for a swim. What attracted me most to ethology was that the ethologists I met were enthusiastic about naturally-occurring behaviour and strongly motivated to describe it as thoroughly as possible. This seemed to me like real science. One must first know what the organism was like on an everyday basis before intervening with an experiment or questionnaire. In my attempt to apply ethology to studying children, I made at least one egregious mistake. I started filming too much behavior - first with a windup camera, then with a video camcorder. Today my behaviour archive is immense and will outlive me for sure. But not as long as Eibl's: he has more film documents than I have by a factor of at least a thousand.

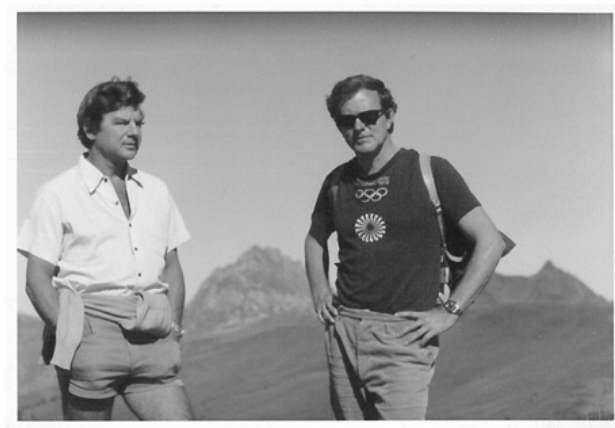

Eibl and Bill Charlesworth 1973 Rossgruber Austria (Photo credit: Unknown) 


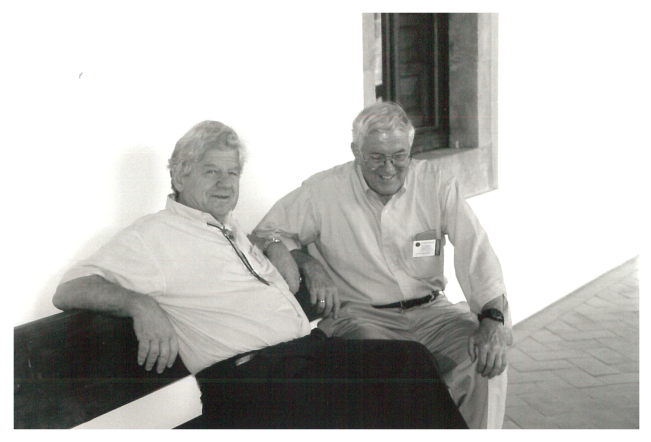

Eibl and Bill Charlesworth 2001 ISHE Salamanca (Photo credit: Peter LaFreniere)

Apropos filming, I was present when Eibl actually set down his trusty camera and, under pressure from me, took my video camcorder in his hand. We were in New Delhi at the time, and I was videoing migrant workers who were digging a ditch near our hotel. Having taken still photos of the workers weeks earlier, I got to know them pretty well so I felt I owed them something. On my final day there, I gave Eibl the camcorder to video me handing out the workers photographs of themselves as well as parcels of stuff I collected in the various hotels we stayed in - soap, shampoo, sewing kits, shoe polishing rags. The title of this episode for publication was "Donation behaviour to friendly conspecific strangers". Eibl's eye was good and I am now immortalised on video tape. But having forgotten to press the off button (I never told him where it was - we were men of unremitting action then), the camcorder continued to record everything after the episode - mostly sidewalk, an occasional bush, the sky - much sky - and of course, our conversation which was routine and mostly zany - being exhausted and hot India can bring out the zany. One more anecdote about India - in a remote area south of New Delhi, lies exotic Sariska, a world-famous tiger preserve. We headed there as soon as we could to check out the tigers. This meant getting up before sunrise and jostling in a jeep for kilometres in the cold. On the first morning, we hit a sandy area and the driver 
stopped and pointed. There in the sand was a large paw print. "Tiger", he muttered. Eibl was quiet and looked ahead. There were fresh tire tracks from a jeep that apparently had preceded us a bit earlier. Eibl turned to me and said loudly, "That guy in the jeep in front of us has this stick with a tiger paw carved in one end to make paw prints." Then I suddenly remembered I had been on this same trail with Indian friends a month earlier before Eibl arrived and the same thing happened. Tourists must be entertained.

As is well known, Eibl has the world's largest documentation of human flirting behaviour - up close facial expressions - containing hundreds of flirtees from many countries.

Having been trained as an experimental psychologist of sorts, I kept pushing Eibl on the need to document the stimulus of this interesting bit of unstaged behaviour. He agreed. So I took my camera and accompanied him on his search for new filming opportunities. This was in Schwabing, München. The setting was an outdoor café, the lighting was good, the frequency of subjects large. Eibl dressed as a safari film producer, set up his tripod, adjusted his angle lens, zoomed in and waited, hoping to release flirting behaviour by occasionally looking at the flirtee and smiling. Eibl was the stimulus. I then drifted nonchalantly three meters behind and a bit to the left of the unwitting subject. We were sure we weren't obvious. Guys dressed like us are frequently seen wandering around Schwabing acting artistic.

Soon the subject reacted - I think. My focus was on Eibl, but the sun kept blinding me. Occasionally, though, I got a glimpse of Eibl, standing there confident and gemutlich with a periodic smile that was to serve as a releaser. But no eyebrow-raisings: that was the job of the flirtee. The study was going well, but suddenly the subject put on her sun glasses.

Other potential research subjects either had sun glasses on or were sitting with their backs to the sun. End of science expedition. There was nothing to do but seek consolation at a nearby Biergarten. One other biology lesson I learned from Eibl needs to be passed on to those who 
hike in the high alps. Breathing hard needs to be counterbalanced by something more intellectual. With Eibl as our guide, the moment of intellectual excitement usually came when we were all out of breath but too macho to mention it. The moment began when Eibl stopped, sat down on a stone and then said "Pass auf." He took out his pocket knife, opened it, picked up a stone - any stone, remember unstaged behaviour - and scraped its surface with the knife blade. He then spit on his finger and rubbed moisture over the scraped surface. Invariably (so far, four out of four times) a green smudge appeared. "Endolithic lichen. Isn't it wonderful. Up here in this cold, windy place, this teensy-weensy, this itsy-bitsy little life thrives. It sets up a place to live here, on this freezing rock, and grows and grows." Eibl was ecstatic. He loved this presence of little life in such an inhospitable place. He also loves the little life in the tiny, hospitable pond behind his home. Before dinner guests arrive, Eibl often engages in one of his favourite hobbies. Taking a small plastic tube, he collects a bit of pond water, puts a drop of it on a microscope slide and gets ecstatic when a small animal with a Latin name appears. Now years later, it dawned on me that Eibl has an enduring love of living things that is worth experiencing. One may even be infected by it. That's a good thing for a budding human ethologist or anyone for that matter. Nicht wahr?

Republished with permission of Peter Lang GmbH, Internationaler Verlag der Wissenschaften, from "Eibl: Loving the Enduring Presence of Little Life", Charlesworth, W., pp 27-31 in (eds Sütterlin, C. \& Salter, F.K.) Irenäus Eibl-Eibesfeldt: zu Person und Werk, 2001; permission conveyed through Copyright Clearance Center, Inc. 